\title{
PENGARUH STRATEGI PEMBELAJARAN GENERATIVE LEARNING TERHADAP KEMAMPUAN MENGARANG NARASI SISWA KELAS X SEMESTER GENAP SMA NEGERI 1 NATAR LAMPUNG SELATAN
}

\author{
Rohana, Eva Nurchurifiani, Riska Alfiawati \\ STKIP PGRI Bandar Lampung \\ Email: rohanaana566@gmail.com, churifiani@gmail.com, riskaalfiawati@gmai.com
}

\begin{abstract}
Informasi Artikel Abstrak

Kata kunci:

Generative learning,

Kemampuan menulis

karangan,

t-test,

Diterima: 26-09-2020

Disetujui: 21-10-2020

Dipubikasikan: 26-10-2020

Tujuan penelitian ini adalah untuk mengetahui pengaruh strategi pembelajaran generative learning terhadap kemampuan menulis karangan narasi siswa SMA di Natar Lampung Selatan. Metode yang digunakan dalam penelitian ini adalah metode eksperimen, populasi berjumlah 175 siswa yang terbagi ke dalam 5 kelas. Sampel sebanyak 2 kelas yaitu kelas $\mathrm{X}_{1}$ sebagai kelas eksperimen, dan kelas $\mathrm{X}_{2}$ sebagai kelas kontrol. Teknik sampling yang digunakan dalam penelitian ini adalah cluster random sampling. Teknik pengumpulan data yang penulis gunakan dalam penelitian ini teknik tes yang berupa sejumlah soal yang harus di jawab oleh siswa guna mengetahui presentasinya dengan memberikan tes menulis karangan narasi. Analisis data dalam pengujian hipotesis menggunakan rumus t-test. Hasil pengujian hipotesis diperoleh hasil $t_{\text {tes }}=5,39$ dan $t_{\text {tab }}=2,00$ dan 2,66 berarti $t_{\text {hit }}>t_{\text {tabel, }}$ maka disimpulkan "ada pengaruh strategi pembelajaran generative learning terhadap kemampuan menulis karangan narasi siswa kelas X semester genap SMA Negeri 1 Natar Lampung Selatan Tahun Pelajaran 2015/2016". Kemampuan mengarang narasi siswa kelas eksperimen yang pembelajarannya diajar menggunakan strategi pembelajaran generative learning memperoleh nilai rata-rata 73,83 sedangkan kelas yang diajar menggunakan strategi pembelajaran konvensional mendapatkan nilai rata-rata 59,42 maka dapat ditarik kesimpulan bahwa Rata-rata kemampuan mengarang narasi siswa pada kelas eksperimen lebih tinggi dibandingkan dengan kelas kontrol.
\end{abstract}

\section{PENDAHULUAN}

Pendidikan merupakan suatu wadah yang berfungsi untuk mempersiapkan sumber daya manusia yang mempunyai kompetensi dalam menjalankan fungsi kehidupan. Sistem pendidikan tidak boleh terlepas dari perubahan yang terjadi di berbagai bidang sebagai akibat arus globalisasi. Pesatnya perkembangan ilmu pengetahuan dan teknologi sekarang ini dapat memberikan pengaruh yang signifikan terhadap dunia Pendidikan. Sebagai upaya mencerdaskan kehidupan bangsa, maka peningkatan mutu pendidikan menjadi hal 
yang sangat penting bagi pembangunan berkelanjutan di segala aspek kehidupan manusia (Rachmadtullah et al., 2020). Sistem pendidikan nasional senantiasa harus dikembangkan sesuai dengan kebutuhan dan perkembangan yang terjadi baik di tingkat lokal, nasional, maupun global.

Pembelajaran diarahkan menuju peningkatan kemampuan berpikir dan terarah terhadap keterampilan siswa dalam belajar, salah satunya pada pelajaran Bahasa Indonesia di sekolah (Setiawan et al., 2020). Dalam Pembelajaran Bahasa dan Sastra Indonesia, menulis atau mengarang merupakan keterampilan yang sangat penting dalam kehidupan, tidak hanya penting dalam kehidupan pendidikan, tetapi juga sangat penting dalam kehidupan bermasyarakat (Ningrum, 2010). Dengan menulis karangan, siswa dapat mengungkapkan atau mengekspresikan gagasan atau pendapat, pemikiran, dan perasaan yang dimiliki. Selain itu, dapat mengembangkan daya pikir dan kreatifitas siswa dalam menulis karangan (Dalman, 2012).

Kemampuan mengarang salah satunya dapat dituangkan dalam bentuk narasi. Mengarang narasi merupakan karangan yang menceritakan suatu peristiwa atau kejadian dengan tujuan agar pembaca seolah-olah mengalami peristiwa tersebut atau kejadian yang diceritakan itu (Hartinah \& Abdullah, 2019; Saputra, 2020). Kemampuan berbahasa seorang siswa merupakan salah satu faktor yang turut menentukan keberhasilan siswa dalam menempuh proses belajar di sekolah. Untuk memperoleh kemampuan berbahasa itu, diperlukan adanya cara mengajar yang komunikatif antara guru dan siswa. Namun melihat dari kenyataan yang ada, pembelajaran mengarang masih sulit dikuasai siswa (Hajaroh \& Adawiyah, 2018; Mantasiah et al., 2017).

Untuk mengatasi permasalahan tersebut, diperlukan suatu strategi pembelajaran untuk menggali pengetahuan siswa dalam menulis karangan narasi, yaitu dengan strategi pembelajaran generative learning yang merupakan model yang menekankan pada integrasi yang aktif antara materi atau pengetahuan baru yang diperoleh dengan skemata (Mawaddah \& Anisah, 2015; Rosdianto, 2017). Dengan menggunakan model generative learning diharapkan siswa menjadi lebih melakukan proses adaptasi ketika menghadapi stimulus baru. Selain itu, sebagai strategi pembelajaran yang berlandaskan konstruktivisme, generatif learning juga berfokus pada keterlibatan dan partisipasi siswa secara aktif dalam proses belajar sebagai tujuan utama dalam proses belajar (Utami, 2018). Berdasarkan uraian tersebut, tujuan penelitian ini adalah untuk mengetahui pengaruh strategi pembelajaran generative learning terhadap kemampuan menulis karangan narasi siswa khususnya Sekolah Menengah Atas di Natar Lampung Selatan.

\section{METODE}

Metode yang digunakan dalam penelitian ini adalah metode eksperimen dengan strategi pembelajaran generative learning. Sampel dalam penelitian ini adalah 175 siswa kelas X semester genap SMA Negeri 1 Natar Lampung Selatan Tahun Pelajaran 2015/2016 yang terdiri atas 86 laki-laki dan 89 perempuan. Sampel tersebut dibagi menjadi 2 kelas yaitu kelas $\mathrm{X}_{2}$ sebagai kelas eksperimen, dan kelas $\mathrm{X}_{3}$ sebagai kelas kontrol. Teknik sampling yang digunakan dalam penelitian ini adalah cluster random sampling. Teknik pengumpulan data yang digunakan dalam penelitian ini teknik tes yang berupa sejumlah soal yang harus di jawab oleh siswa guna 
mengetahui presentasinya dengan memberikan tes menulis karangan narasi. Analisis data dalam pengujian hipotesis menggunakan rumus $t$-test. Hipotesis dari penelitian ini sebagai berikut,

$$
\begin{aligned}
& \text { Ho }=\mu_{1}=\mu_{2} \text { Tidak ada strategi pembelajaran generative learning terhadap kemampuan menulis karangan } \\
& \text { narasi siswa kelas X semester genap SMA Negeri } 1 \text { Natar Lampung Selatan Tahun } \\
& \text { Pelajaran } 2015 / 2016 \\
& \text { Ho }=\mu_{1} \neq \mu_{2} \quad \text { Ada pengaruh strategi pembelajaran generative learning terhadap kemampuan menulis } \\
& \text { karangan narasi siswa kelas X semester genap SMA Negeri } 1 \text { Natar Lampung Selatan } \\
& \\
& \text { Tahun Pelajaran 2015/2016 }
\end{aligned}
$$

\section{HASIL DAN PEMBAHASAN}

\section{Hasil Tes Siswa}

Untuk menguji kebenaran dari hipotesis, maka penulis mengumpulkan data yang berbentuk angka-angka atau nilai dengan teknik tes yang berupa sejumlah soal yang harus di jawab oleh siswa guna mengetahui presentasinya dengan memberikan tes menulis karangan narasi. Hasil dari tes tersebut ditunjukkan pada tabel 1.

Tabel 1. Hasil dari tes kelas eksperimen dan kontrol

\begin{tabular}{lccccc}
\hline Sampel & frekuensi & Nilai Maks. & Nilai Min. & Rata-rata & Standar deviasi \\
\hline Kelas Eksperimen & 36 & 97 & 45 & 73,83 & 12,99 \\
\hline Kelas Kontrol & 36 & 84 & 33 & 59,42 & 13,88 \\
\hline
\end{tabular}

Berdasarkan data, kelas eksperimen memiliki nilai rata-rata 73,83, nilai maksimum 97, dan nilai minimum 45. Di sisi lain, kelas kontrol memiliki nilai rata-rata 59,42, nilai maksimum 84, dan nilai minimum dari 33.

\section{Uji Normalitas}

Hasil penelitian yang valid dan dapat dipertanggung jawabkan maka sebelum dilaksanakan pengujian hipotesis harus diketahui sebaran data tersebut berdistribusikan normal serta homogen. Hal ini untuk menghindari kesalahan dalam penarikan kesimpulan akibat penggunaan rumus statistik yang tidak sesuai. Dalam hal ini tabulasi di atas selanjutnya dihitung. Hasil uji normalitas pada masing-masing kelas ditunjukkan pada tabel 2.

Tabel 2. Hasil uji normalitas kelas eksperimen dan kontrol

\begin{tabular}{lcc}
\hline \multicolumn{1}{c}{ Sampel } & $\mathbf{X}^{2}{ }_{\text {hitung }}$ & $\mathbf{X}^{2}$ tabel \\
\hline Kelas Eksperimen & 3,21 & 7,81 \\
\hline Kelas Kontrol & 4,23 & 7,81 \\
\hline
\end{tabular}

Dari tabel 1 terlihat bahwa pada taraf signifikan 0,05 ternyata baik kelas eksperimen dan kontrol memiliki hasil $\mathrm{X}^{2}$ hitung yang lebih kecil dibandingkan $\mathrm{X}_{\text {tabel }}^{2}$ sehingga hipotesis Ho diterima, berarti sample berasal dari populasi berdistribusi normal. 


\section{Uji Hipotesis}

Strategi pembelajaran generative learning merupakan suatu pembelajaran yang menekankan pada pengintegrasian secara aktif pengetahuan baru dengan menggunakan pengetahuan yang sudah dimiliki siswa sebelumnya. Pengetahuan baru itu akan diuji dengan cara menggunakannya dalam menjawab persoalan atau gejala yang terkait. Apabila pengetahuan baru itu berhasil menjawab permasalahan yang dihadapi, maka pengetahuan baru itu akan disimpan dalam memori jangka panjang.

Hasil pengujian menggunakan $t$-test didapatkan nilai thitung $=5,39$. Sedangkan untuk tabel distribusi pada taraf signifikan $5 \%$ diketahui $t_{\text {tab }}=2,00$ dan 2,66. Dari hasil tersebut dapat terlihat bahwa $t_{\text {hit }}>t_{\text {tabel }}$ sehingga dapat dinaytakan bahwa $\mathrm{H}_{\mathrm{o}}$ ditolak dengan kata lain dapat disimpulkan bahwa "ada pengaruh strategi pembelajaran generative learning terhadap kemampuan menulis karangan narasi siswa kelas X semester genap SMA Negeri 1 Natar Lampung Selatan Tahun Pelajaran 2015/2016”. Kemampuan mengarang narasi siswa kelas eksperimen yang pembelajarannya diajar menggunakan strategi pembelajaran generative learning memperoleh nilai rata-rata 73 sedangkan kelas yang diajar menggunakan strategi pembelajaran konvensional mendapatkan nilai rata-rata 58,5 maka dapat ditarik kesimpulan bahwa Rata-rata kemampuan mengarang narasi siswa pada kelas eksperimen lebih tinggi dibandingkan dengan kelas kontrol.

\section{KESIMPULAN}

Penelitian untuk menguji pengaruh strategi pembelajaran generative learning terhadap kemampuan menulis karangan narasi siswa SMA di Natar Lampung Selatan telah berhasil dilakukan. Hasil pengujian hipotesis diperoleh hasil $\mathrm{t}_{\mathrm{tes}}=5,39$ dan $\mathrm{t}_{\mathrm{tab}}=2,00 \mathrm{dan} 2,66$ berarti $\mathrm{t}_{\text {hit }}>\mathrm{t}_{\mathrm{tabel}}$, maka disimpulkan "ada pengaruh strategi pembelajaran generative learning terhadap kemampuan menulis karangan narasi siswa kelas X semester genap SMA Negeri 1 Natar Lampung Selatan Tahun Pelajaran 2015/2016”. Kemampuan mengarang narasi siswa kelas eksperimen yang pembelajarannya diajar menggunakan strategi pembelajaran generative learning memperoleh nilai rata-rata 73,83 sedangkan kelas yang diajar menggunakan strategi pembelajaran konvensional mendapatkan nilai rata-rata 59,42 maka dapat ditarik kesimpulan bahwa Rata-rata kemampuan mengarang narasi siswa pada kelas eksperimen lebih tinggi dibandingkan dengan kelas kontrol.

\section{DAFTAR PUSTAKA}

Dalman. (2012). Keterampilan Menulis. Raja Grafindo.

Hajaroh, S., \& Adawiyah, R. (2018). Kesulitan Guru Dalam Mengimplementasikan Penilaian Autentik. El Midad, 10(2), 131-152.

Hartinah, H., \& Abdullah, S. I. (2019). Pengaruh Minat Baca dan Persepsi Atas Perpustakaan Sekolah terhadap Keterampilan Menulis Narasi. Diskursus: Jurnal Pendidikan Bahasa Indonesia, 1(02), 127-135.

Mantasiah, R., Juffri, J., \& Yusri, Y. (2017). Keefektifan Model Pembelajaran Jaring Laba-Laba (Webbed) dalam Keterampilan Menulis Karangan Sederhana Bahasa Jerman. Indonesian Journal of Educational Studies, 20(2). 
Mawaddah, S., \& Anisah, H. (2015). Kemampuan pemecahan masalah matematis siswa pada pembelajaran matematika dengan menggunakan model pembelajaran generatif (generative learning) di SMP. EDUMAT: Jumal Pendidikan Matematika, 3(2).

Ningrum, T. A. (2010). PENINGKATAN KETERAMPILAN MENULIS KARANGAN NARASI DENGAN TEKNIK MENGARANG TERPIMPIN MELALUI PEMANFAATAN MEDIA GAMBAR BERSERI PADA SISW A KELAS XB SMA SANTA MARLA REMBANG TAHUN PELAJARAN 2009/2010. Universitas Negeri Semarang.

Rachmadtullah, R., Yustitia, V., Setiawan, B., Mahya Fanny, A., Pramulia, P., Susiloningsih, W., Tur Rosidah, C., Prastyo, D., \& Ardhian, T. (2020). The Challenge Of Elementary School Teachers To Encounter Superior Generation In The 4.0 Industrial Revolution: Study Literature. International Journal of Scientific \& Technology Research, 9(4), 1879-1882. www.ijstr.org

Rosdianto, H. (2017). Pengaruh Model Generative Learning Terhadap Hasil Belajar Ranah Kognitif Siswa Pada Materi Hukum Newton. Jumal Pendidikan Fisika Dan Keilmuan (JPFK), 3(2), 66-69.

Saputra, H. (2020). KEMAMPUAN MENULIS KARANGAN NARASI SISWA KELAS V SDN 3 MARGODADI JATI AGUNG LAMPUNG SELATAN. Prosiding Seminar Nasional STKIP PGRI Bandar Lampung, 181-200.

Setiawan, B., Rachmadtullah, R., \& Iasha, V. (2020). Problem-Solving Method: The Effectiveness of The Preservice Elementary Education Teacher Activeness in The Concept of Physics Content. Jurnal Basicedu, 4(4), 1074-1083.

Utami, I. Y. Y. W. (2018). KOMPARASI MODEL PEMBELAJARAN GENERATIF D AN MODEL PEMBELAJARAN CONTEXTUAL TEACHING AND LEARNING (CTL) DITINJAU D ARI KEMAMPUAN KOMUNIKASI MATEMATIS SISWA. Universitas Mercu Buana Yogyakarta. 